\title{
ELECTRE-Entropy method in Group Decision Support System Modelto Gene Mutation Detection
}

\author{
Ermatita \\ Department of Information System, Computer Science \\ Faculty of SriwijayaUniversity,Palembang, Indonesia \\ (Doctoral Program Student Computer Science \\ GadjahMadaUniversity ) \\ Retantyo Wardoyo \\ Departement of Computer Science and Electronics \\ Mathematics and Natural Sciences Faculty GadjahMada \\ University, Indonesia
}

\begin{abstract}
Application of Group Decision Support System (GDSS) can assist for delivering the decision of various opinions (preference) cancer detection based on the preferences of various expertise. In this paper we propose ELECTRE-Entropy for GDSS Modeling. We propose entropy weighting for each criteria under ELECTRE Method.ELECTRE is one method in MultiAttribute Decision Making (MADM). Modeling of Group Decision Support Sytemapplyfor multi-criteria which the simulation data mutated genes that can cause cancer and solution recommended.
\end{abstract}

Keywords-component; Group decision support system(GDSS); Multi Atributte Decision making(MADM); Electre-entropy; preference.

\section{INTRODUCTION}

To Determine wheather a person has abnormal gene of cancer-causing can be done from different areas of expertise in medical science, such as pathologist, oncology or other disciplines in medicine. The opinions in various expert in medical science requires decision that could provide treatman provision against person alleged having abnormal genes as the cause of cancer. Group Decision Support System is one of application in information technology that can assist in delivering the decision from various opinion (preferences) for detecting person having mutated gene that causes cancer based on the preferences of various expertise.

The decision making process requires the aggregation method to get single value of each alternative from variety of criteria. In the decision-making system, this problem can be solved by Multiple Criteria Decision Making (MCDM). The study of MCDM has begun to emerge in the late 19th century. But the very rapid development of new beginning to be felt since the 1970s, especially in the field of operations research (Suiran, et al; 2001; Sage, 1991).

This study establish Clinical Model Group Decision Support System (CGDSS) where knowledge base is built based on preferences that differ from the experts of different expertise

\author{
Sri Hartati \\ Departement of Computer Science and Electronics \\ Mathematics and Natural Sciences Faculty GadjahMada \\ University, Indonesia
}

\author{
Agus Harjoko \\ Departement of Computer Science and Electronics \\ Mathematics and Natural Sciences Faculty GadjahMada \\ University, Indonesia
}

from the classification genes with SVM method uses the concept of multi-attribute decision making (MADM).

\section{BACKGROUND THEORIES}

\section{A. Group decision support system (GDSS)}

Group decision support system (GDSS) is an interactive computer-based system that facilities the solution of semistructured or unstructured problems by a group of decision maker.[11]

GDSS has several major characteristics,i.e.:

- GDSS has goal to support the process of group decision makers by providing automation of subprocesses, using information technology tools.

- GDSS is specially designed information system, not merely a configuration of already existing system components. It can be designed tobe address one type of problem or a variety of group-level organizational decisions.

- GDSS encourages generation of ideas, resolution of conflicts, and freedom of expression. It contains builtin mechanismes that discourage development of negative group behaviors, such as destructive conflict, miscommunication, and groupthink.(Turban,2011)

ELECTRE (Elimination EtChoixTraduisant la realite) is one method in MADM based on the concept of ranking through pairwise comparisons between alternatives on the appropriate criteria. An alternative is said to dominate another alternative if one or more of the criteria are exceeded (compared with the other criteria of alternative) and the same with the remaining criteria. The relationship between the two alternatives Ak ranking of the A1 (Roy, 1973)in [4]

MADM is evaluated against the alternative $\mathrm{m} \mathrm{Ai}(\mathrm{i}=$ $1.2, \ldots ., \mathrm{m})$ of a group of attributes or criteria $\mathrm{c},(\mathrm{j}=1.2, \ldots, \mathrm{n})$ where each of the attributes are not mutually dependent on one 
other. Decision matrix of each alternative on each attribute, $\mathrm{X}$ is given as:

$X=\left[\begin{array}{cccc}x_{11} & x_{12} & \cdots & x_{1 n} \\ x_{21} & x_{22} & \cdots & x_{2 n} \\ \vdots & \vdots & \cdots & \vdots \\ x_{m 1} & x_{m 2} & \cdots & x_{m n}\end{array}\right]$

The Procedure of using ELECTRE is shown as follows :

1) In ELECTRE. First the weightted normalized impact matrix of $\mathrm{V}_{\mathrm{ij}}$ is computed to provide a dimensionless environment. This step is the same as the first two steps describes in:

$$
V_{i j}=w_{j} x_{i j}
$$

2) The concordance set cij, is determined for each pair of alternatives $\mathrm{j}$ an $\mathrm{j} * \mathrm{i}$.e the setr of criteria for attributes in which the impact of alternative $\mathrm{j}$ is better than or equal to that of alternative $j^{*}$. Similarly, a discordance set Dij is define which compares two alternatives in which alternative i perform worse tha alternative $\mathrm{i}$ :

$$
\begin{aligned}
& \mathrm{C}_{\mathrm{kl}}=\left\{\mathrm{j} \mid \mathrm{v}_{\mathrm{kj}} \geq \mathrm{v}_{\mathrm{ij}}\right\} \text { untuk } \mathrm{j}=1,2, \ldots, \mathrm{n} \\
& \text { And } \mathrm{d}_{\mathrm{kl}}=\left\{\mathrm{j} \mid \mathrm{v}_{\mathrm{kj}}<\mathrm{v}_{\mathrm{ij}}\right\} \text { untuk } \mathrm{j}=1,2, \ldots, \mathrm{n}
\end{aligned}
$$

Where vkj and vij are impact values with the ith criterion and 1 is the set of atributes

3) Once the concordance and disconcordance sets are found, concordonce $\left(\mathrm{c}_{\mathrm{ij}}\right)$ and disconcordance $\left(\mathrm{d}_{\mathrm{ij}}\right)$ indices can be calculated respectively. The concordance index is equal to the sum of the weights associated with the ith attribute which are contained in the concordance set. Hence, the formula is shown as follows :

$$
C_{k l}=\sum_{j \in c_{k l}} w_{j}
$$

Where $\mathrm{w}_{\mathrm{i}}$ is the weight of the $\mathrm{i}^{\text {th }}$ attribute and $0<\mathrm{cij}<1$.the concordance index reflects the relative importance of alternative $\mathrm{j}^{*}$. A higher value of $\mathrm{c}_{\mathrm{ij}}$, indicates that alternatives $\mathrm{j}$ is preferred to $\mathrm{j}^{*}$ as far as the concordance attributes are concerned. In addition, disconcordanceindex(dij)can be calculated such that:

$$
d_{k l}=\frac{\max \left\{v_{k j}-v_{i j}\right\}_{j \in d_{k l}}}{\max \left\{\left|v_{k j}-v_{i j}\right|\right\}_{j \in v_{j}}}(5)
$$

Where vkj and vij are the data in normalized impact matrix and 1 is the set of attributes.[19]

Concordance matrix calculated based on the dominant [10]

$$
f_{k l}=\left\{\begin{array}{lll}
1, & j i k a & c_{k l} \geq \underline{c} \\
0, & j i k a & c_{k l}<\underline{c}
\end{array}\right.
$$

elements of the matrix $\mathrm{F}$ is determined as the dominant discordance:

$$
g_{k l}=\left\{\begin{array}{lll}
1, & \text { jika } & d_{k l} \geq \underline{d} \\
0, & j i k a & d_{k l}<\underline{d}
\end{array}\right.
$$

Aggregation of the dominant matrix (E) showing a partial preference order of alternatives, obtained with the formula in mathlab:

$e_{k l}=f_{k l} \cdot g_{k l}(8)[4]$

\section{B. Entropy}

Entropymethodcan be usedtodeterminetheweights. Entropyconsistencyininvestigatingdiscriminationamonga set of data.Alternativeset of datavaluesoncertaincriteriadescribedin theDecisionMatrix(DM). Using theentropymethod, thevariationvaluecriterionwill be canhighestweights. [12]

The measuresusedin this methodare asfollows:

- Creating The andquantitativecriteria, but allmustbemeasurable.

- Normalizationof datatableof criteria

$$
\left[\begin{array}{l}
d_{i}{ }^{k}={\frac{x_{i}^{k}}{x_{i}^{k}}}_{\text {maks }} \\
D_{i}=\sum_{k=1}^{m} d_{i}^{k} \quad i=1,2, \ldots, n . .
\end{array} \quad \mathrm{d}_{\mathrm{i}}=\mathrm{d}_{\mathrm{i}}{ }_{i}, \ldots, \mathrm{d}_{\mathrm{i}}^{\mathrm{m}}\right.
$$

After getting Entropy weighting for each criterion, if it has no initial weight or weight of a predetermined weight of Entropy then the truth to each criterion will be obtained with the following calculation

$$
\lambda_{i}=\frac{\overline{\lambda_{1}} \times w_{1}}{\sum_{i=1}^{n} \overline{\lambda_{1} \times w_{1}}} \quad \mathrm{i}=1, \ldots \ldots, \mathrm{n}
$$

\section{Copeland score}

The Copeland Score is more likely to produce ties, since it does not take into account the margin of victory, or the magnitude of support. In some contests, a Copeland Score will not identify a clear winner and provide only a limited differentiation between the options. In a three-way contest with no Condorcet winner and no ties in the binary contests, all three candidates will have the same Copeland score (each will have 1 win, 1 loss). In a four-way contest without a Condorcet winner, there will be at best a two-way tie ( 2 wins, 1 loss each). Consequently, many contests will need some secondary mechanism to resolve contests which end in a tie. [28]

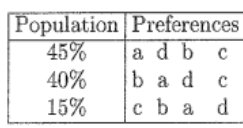

Preference profiles

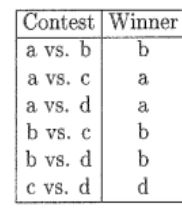

Pair-wise contests

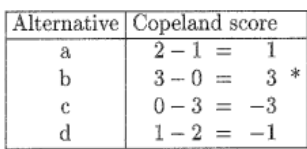

Voting Results
Figure 1. Copeland Score 


\section{ELECTRE-ENTROPY METHOD FOR GROUP DECISION SUPPORT SYSTEM MODEL GENE MUTATION DETECTION}

Process in group decision support system begins with this clinical classification process, the process of ranking the decision, then made a decision ranking of the ranking recommendations of each expert. This system has three engine block in the decision-making systems like the picture below

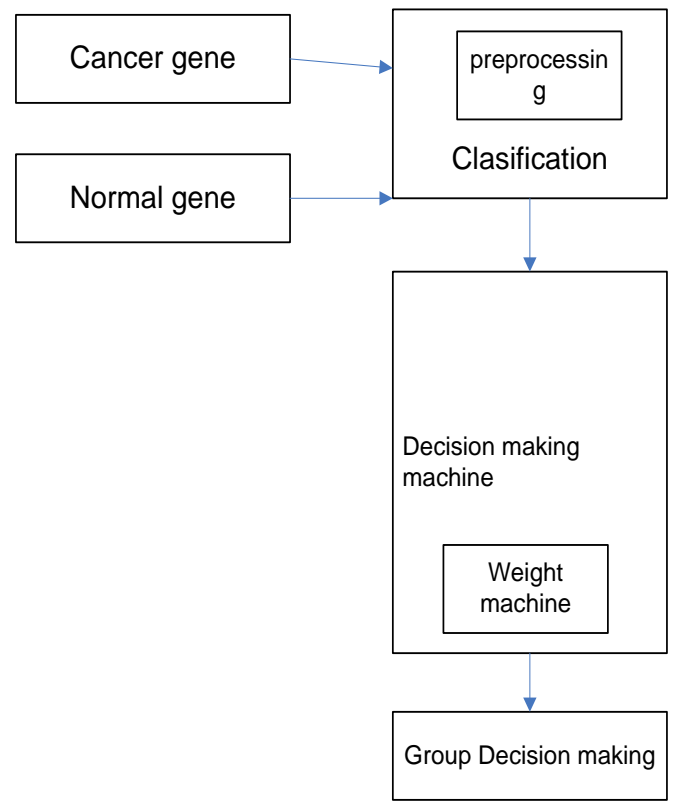

Figure 2. Architecture model of GDSS (Group Decision Support System) for Decision Making.

Materials are processed in the architecture of this system is the data model of cancer gene available on the Internet.

The data that exists is shaped gene sequences that would later be classified into training data and testing data.

Components in the engine builders are composed of:

1) Classification engine. This component is assigned toperform the classification of the existing gene data. In thismachine used the method of classification with SupportVector Machine method.

2) Machine Builders Decision. These components perform ranking and data processing as preferences given by the experts. The model built in the engine builders these decisions using Multi Attribute Decision Making with ELECTRE methods.

3) Weighting machine. Decision builder method that does the determination of the ideal weight in development decisions. The resulting weights will be used in the ranking of each expert's decision.

4) Decision maker. This component is the decision maker has been obtained from each expert. Recommendations in order to get better decisions. In this machine used method of Copeland score.

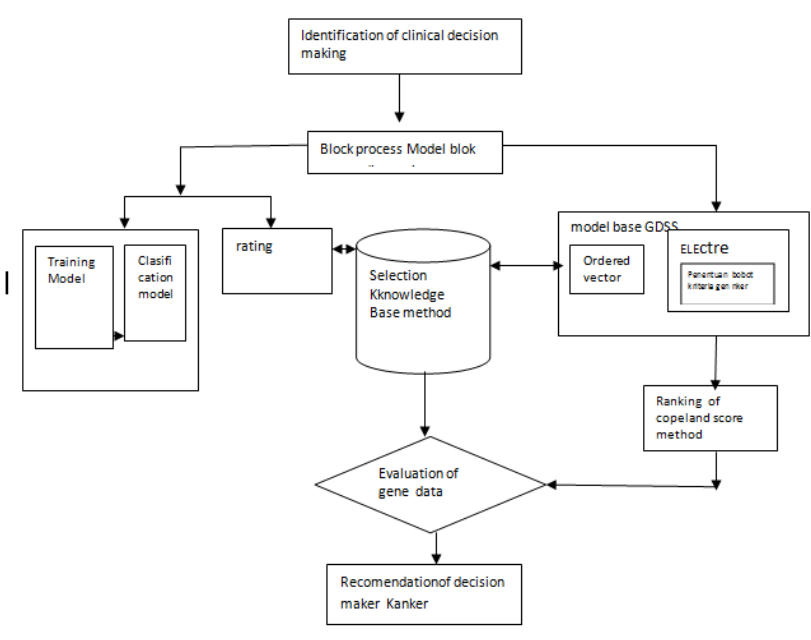

Figure 3. CGDSS Model: Modeling Preferences and skills base on Classification as Model in Group Decision Support System for Decision Making (adapted from Deng, 2008)

\section{A. Classification}

Protein sequence data from the example above would convert the system into the strands of the DNA sequence consisting of A, G, C and T. DNA strands will be made in two dimensions in the number of $\mathrm{A}$ and $\mathrm{T}$ number of $\mathrm{G}$ and $\mathrm{C}$. Then do the process of classification with Support Vector Machine method. The conversion process is done by creating a numerical code for each letter in the DNA sequence code. Values that have been in this conversion will be processed by the method of classification by support vector machine, getting class genes of normal and abnormal.

In Support Vector Machine, best Hyperplane / clasifier is located in the middle between the two groups of objects from two classes, namely class of normal genes and gene abnormalities. In the classification process to maximize this margin, the system will determine the class of data to be ranked in the training class, after being found clasifier. Performance is good, It will be set classroom testing. If the class already exists then this testing will be used other data to be processed classification. Looking for the best hyperplane is to maximize the margin or distance between the two groups of objects from different classes of genes.

\section{B. Model}

Group Decision Support System base with ELECTREmethod-Entropy Classification results will be analyzed by specialists. This analysis will refer to the provision of suitability rating on each criterion for the count with ELECTRE method. This modeling begins with the preparation component of alternatrive the situation in the identification. The objectives of the component preparation is to construct a table of estimated components of the situation and identification of alternatives, specification of objectives, criteria and attributes. This model is used to evaluate alternative $\mathrm{m} \mathrm{Ai}(\mathrm{i}=1,2, \ldots \ldots ., \mathrm{m})$ against a set of attributes or criteria $\mathrm{Cj}(\mathrm{j}=1,2, \ldots . ., \mathrm{n})$ and attributes are not mutually dependent each other. 
Decision matrix of is built each alternative on each attribute, X. Preparation of the components on this modeling is used to detect gene mutations in humans to determine whether there is through virus, nutrition or foreign object. So, the model can detect whether a person is identified to have cancer cells or not.

In this model simulation there are three alternatives that can be set to identify cancer cells in human genes, namely:

$\mathrm{A} 1=$ mutation because the virus

A2 = Mutations for Foreign Objects

A3 = Mutations for Nutrition

There are 3 that a reference in making decisions which are:

$\mathrm{C} 1=$ protein bound to viral

$\mathrm{C} 2=$ Expression HSP

$\mathrm{C} 3=$ proteisn expression containing $\mathrm{CH}_{3}$

Rating the suitability of each alternative on each criterion, the value of 1 to 5 , namely: $1=$ very bad, $2=$ poor, $3=$ quite, $4=$ Good and 5 = Very good. Level of importance of each criterion in value by 1 to 5 , namely:

$1=$ very low, $2=$ Low, $3=$ quite, $4=$ High and $5=$ very high The values given by experts in each alternative on each criterion is the value of a match. Suitability value is simulated as in the following table:

Our model begins by establishing a paired comparison of each alternative on each criterion (xij) which are being formulated in a matrix $X$ as a decision matrix. $X i j$ is a performance rating of alternative $\mathrm{i}$-th $\mathrm{j}$-th attribute. Then we use Copeland score method in making final decision.

Classification block. This component is assigned to perform the classification of the existing gene data. In this block we use Support Vector Machine method. The classification system machine data in the form of the gene will be read from the database. The data in the form of the gene sequences of DNA will be in the formula calculating the number of $\mathrm{A}$ and $\mathrm{T}$, as well as the number of $\mathrm{G}$ and $\mathrm{C}$. $\mathrm{A}$ and $\mathrm{T}$ will be in put in one dimension, then $\mathrm{G}$ and $\mathrm{C}$ are grouped in one dimension.

Data in this dimension has been produced by the process of determining the classification engine to perform training classes. The process will continue until the ideal performance close to $100 \%$ using classification performance. If this figure is already approaching the ideal performance, then the testing class will be performed. Testing this class that will test the incoming data so it will be grouped into normal and abnormal classes. The figure above is result classification of SVM

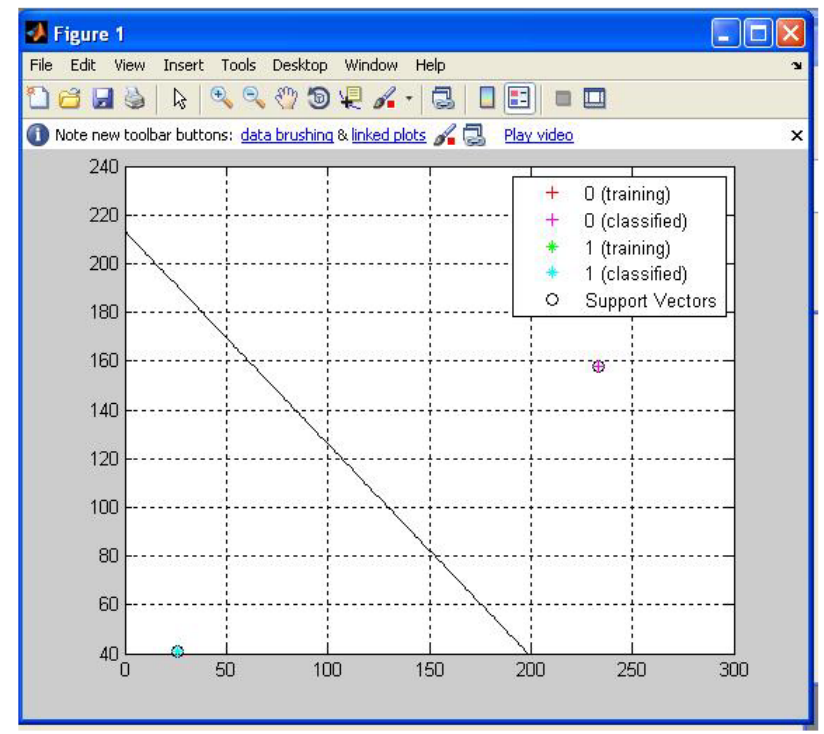

Figure 4. result classification in SVM method

global data1 CP

[a b c d]=mysql('select $*$ from gen'); $\mathrm{f}=[] ; \mathrm{e}=[]$;

fori $=1$ :length $(\mathrm{b})$

$\mathrm{e}(\mathrm{i})=\operatorname{sum}\left(\right.$ ismember $\left.\left(\mathrm{c}\{\mathrm{i}\}, \mathrm{T}^{\prime}\right)\right)+\operatorname{sum}\left(\right.$ ismember $\left.\left(\mathrm{c}\{\mathrm{i}\},{ }^{\prime} \mathrm{A}\right)\right)$;

$f(i)=\operatorname{sum}\left(\right.$ ismember $\left.\left(c\{i\},{ }^{\prime} G^{\prime}\right)\right)+\operatorname{sum}\left(\right.$ ismember $\left.\left(c\{i\},{ }^{\prime} C^{\prime}\right)\right)$;

end

species $=\mathrm{d} ; \mathrm{e}=\mathrm{e}^{\prime} ; \mathrm{f}=\mathrm{f}^{\prime}$;

data $=[\mathrm{e} \mathrm{f}]$;

groups $=$ ismember $\left(\right.$ species, $\left.{ }^{\prime} Y^{\prime}\right)$;

[train, test $]=$ crossvalind ('holdOut', groups);

$\mathrm{cp}=$ classperf(groups);

figure(1);

svmStruct=svmtrain(data(train,:), groups(train), 'showplot',true)

;

gridon;

classes = svmclassify (svmStruct,data(test,:),'showplot',true);

classperf(cp,classes,test);

$\mathrm{CP}=\mathrm{cp}$.CorrectRate;

figure(cp1);

data $1=[\mathrm{b}($ test,:) $\quad \mathrm{c}($ test,:) $\quad \mathrm{d}($ test,:) $\quad$ num2cell(e(test,:)) num 2 cell(f(test,:))];

figure(lihat);

Block Decision. These components perform ranking and processing of data is a preference that is given by the experts. 
The model built in the engine builders these decisions using Multi Attribute Decision Making with ELECTRE methods. The system in this machine will accept input in the form of rating the suitability and weights based on the interests of the experts with an ordered vector format. Each expert provide the weight of each of the criteria based on interests. The ideal weight then calculated with entropy in ELECTRE method. We then can obtain alternative ranking in table below:

TABLE I. SUITABILITY OF EACH ALTERNATIVE ON EACH CRITERION

\begin{tabular}{|c|l|l|l|}
\hline \multirow{2}{*}{ Alternative } & \multicolumn{3}{|c|}{ criteria } \\
\cline { 2 - 5 } & \multicolumn{1}{|c|}{$\boldsymbol{C 1}$} & \multicolumn{1}{c|}{$\boldsymbol{C 2}$} & $\boldsymbol{C 3}$ \\
\hline $\boldsymbol{A 1}$ & 4 & 4 & 5 \\
\hline $\boldsymbol{A 2}$ & 4 & 5 & 4 \\
\hline $\boldsymbol{A 3}$ & 4 & 3 & 5 \\
\hline
\end{tabular}

TABLE II. SUITABILITY OF EACH ALTERNATIVE ON EACH EXPERT

\begin{tabular}{|c|c|c|c|}
\hline \multirow[t]{2}{*}{ Alternative } & \multicolumn{3}{|c|}{ criteria } \\
\hline & $C 1$ & $C 2$ & C3 \\
\hline$P 1$ & 4 & 1 & 1 \\
\hline$P 2$ & 3 & 1 & 1 \\
\hline$P 3$ & 1 & 3 & 3 \\
\hline$P 4$ & 1 & 1 & 1 \\
\hline
\end{tabular}

Result of calculation data for normalization is :

$$
\mathrm{R}=\quad \begin{array}{ccc}
0.4575 & 0.6860 & 0.7071 \\
0.7625 & 0.5145 & 0.5657 \\
0.4575 & 0.5145 & 0.4243
\end{array}
$$

And result of entropy calculation is :

$$
\mathrm{W}=\begin{array}{ccc}
0.3734 & 0.3133 & 0.3133 \\
0.3734 & 0.3133 & 0.3133 \\
0.3734 & 0.3133 & 0.3133
\end{array}
$$

Implementation on matlab the method like follow :

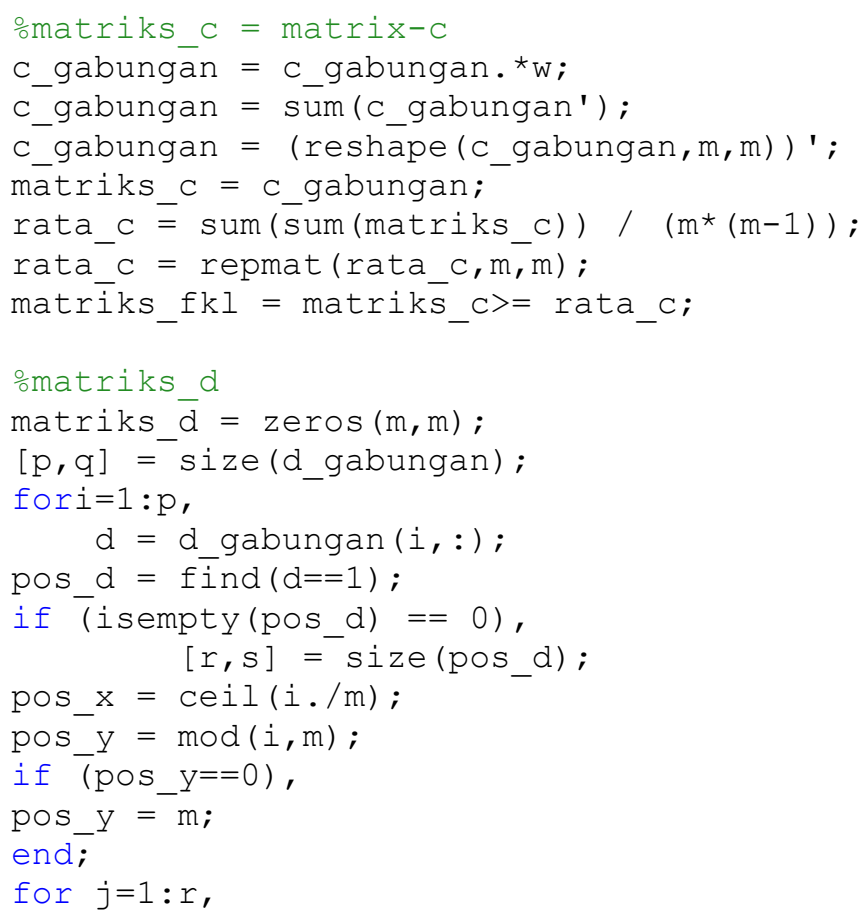

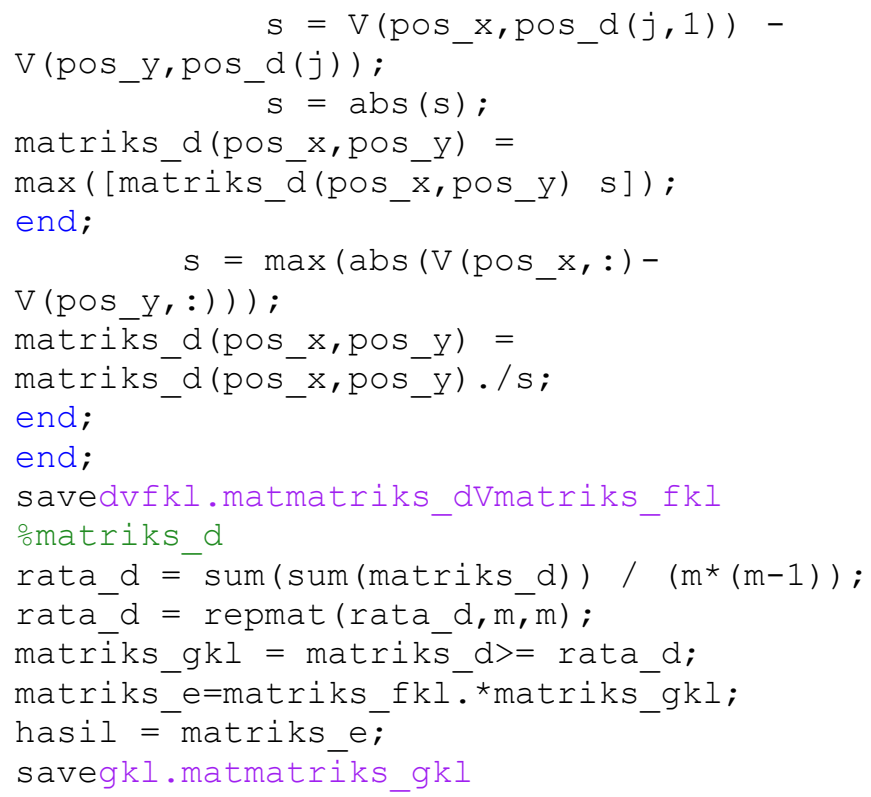

Result of calculation ELECTRE-Entropy method and voting in copeland score as follow:

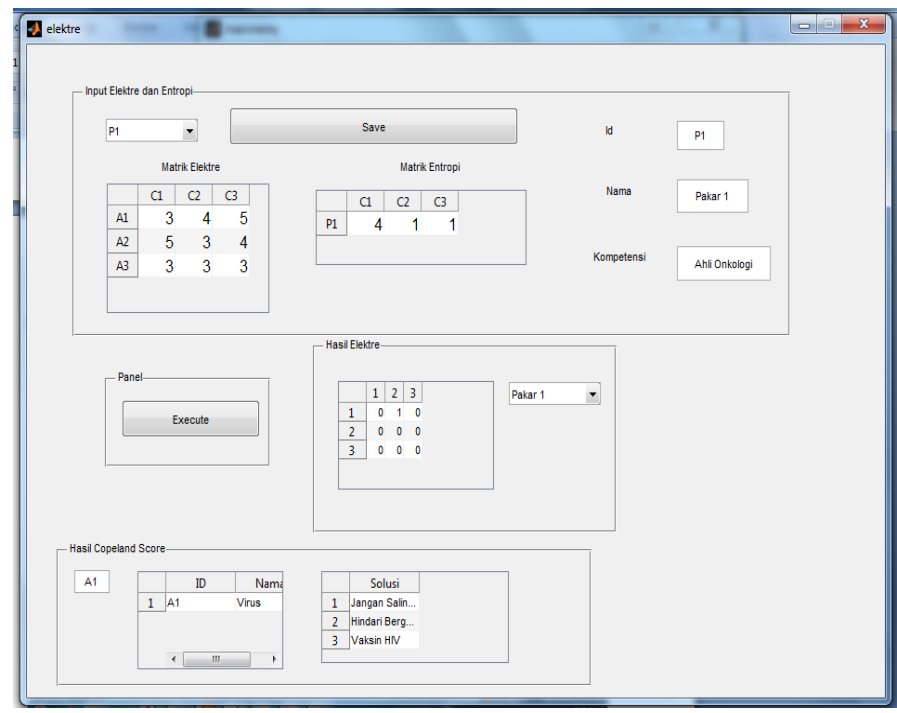

Figure 5. Result of ELECTRE-entropy method and copeland score voting.

The results of calculations with ELECTRE-Entropy modeling with voting Copeland scorec an result in a vote with a value of A1. Figure. 5 copeland score results show tha talternative 1 (A1) is dominant. The result show that the Alternative A1 is recommended as a result of group decisions and the solution recommended.

\section{CONCLUSIONS}

ELECTRE-Entropy modeling method can be helpful in determining alternatives rank.. This modeling can be applied to several other conditions of a similar case.

Calculation of weighting with Entropy method using the preference ofe ach expert candetermine the ideal value of modeling so that can provide recommendations for producing better decisions. 


\section{ACKNOWLEDGMENT}

This work is a continuation of the paper title "Implementation of MADM Methods in Solving Group Decision Support System on Gene Mutations Detection Simulation" Presented at ICCMS at Mumbai and ELECTRE solving Methods in Bioinformatics Group decision support system on gene mutation detection simulation, published on International Journa Computer Science and InformationTechnology.

\section{REFERENCES}

[1] Amiri, "Developing a New ELECTRE Method with Interval Data in MultipleAttribute Decision Making Problems" 2008

[2] Bashiri, "An Extension of Multi-Response Optimization In MADM view", Journal of applied Sciences 9(9); page 1695-1702, 2009

[3] R. Fitriadi, "Pendekatan Compromise Programming dengan memperhitungkan Faktor lingkungan (Studi Kasus Industri Otomotif PT"XX" Jawa Tengah)", Jurnal Ilmiah Teknik Industri Vol. 5 No. 2 Des 2006, hal $72-81,2006$

[4] S. Kusumadewi, S. Hartati, A. Harjoko, dan R. Wardoyo, "Fuzzy Multi-AttributeDecision Making (FUZZY MADM)", Yogyakarta: Penerbit Graha Ilmu, 2006

[5] S. Opricovic, G.H. Tzeng, "Extended VIKOR method in comparison with outranking methods", European Journal of Operational Research 178 (2007) 514-529, 2007

[6] A. Prayitno, et All, "The expression of $\mathrm{p} 53, \mathrm{Rb}$, and c-myc protein in cervical cancer by immunohistochemistry stain", Biodiversitas ISSN: 1412-033X Volume 6, Nomor 3 Juli 2005 Halaman: 157-159, 2005

[7] Soltanmohammadi, "Achieving to some outranking relationships between post mining land uses through mined land suitability analysis", Int. J. Environ. Sci. Tech., 5 (4), 535-546, Autumn 2008 ISSN: 1735$1472 \odot$ Irsen, Ceers, IAU, 2008

[8] E. Turban, "Dicision Support and Expert Systems: Management Support Systems", Fourth Edition, Prentice-Hall,Inc., United State, 2005

[9] Q. Zhang and J. Ma, "Determining Weights of Criteria Based on Multiple Preference Formats", online pada http://www.is.cityu.edu.hk/Research /WorkingPapers/paper/0102.pdf12 Oktober 2004, 2004

[10] Ermatita, et All, MADM Methods in Solving Group Decission support sytem on Gene Mutation Detection simulation, Proceedings The second International Conference on DfmA 2010, ISBN:978-602-9747-9-0-4, August 2010, UGM, Yogyakarta

[11] Turban ,E,et All,2011, Decision Support and Business intelligence Systems, ninth Edition, Pearson education, Inc., publishing as Prentice Hall, new jersey, USA

[12] Vivi Triyanti dan M.T Gadis, 2008, Pemilihan Supplier Untuk Industri Makanan Menggunakan Metode Promethee, Journal of Logistics and Supply Chain Management, Vol 1, No. 2, June 2008: 8392,jurnal.pdii.lipi.go.id/admin/jurnal/12088392.pdf, di akses 24 Mei 2011

[13] Lontar, 2011 Fakultas kedokteran Gigi Universitas Indonesia, www.lontar.ui.ac.id/file?=file digital/125719-Rv-om, Jakarta

[14] Guan.P, Huang.D, He. M and Zhou.B, 2009, Lung cancer gene expression database analysis incorporating prior knowledge with support vector machine-based classification method, Journal of Experimental \&
Clinical Cancer Research 2009, 28:103 doi:10.1186/1756-9966-28-103, http://www.jeccr.com/content/28/1/103

[15] Lee .MC, Jui-Fang Chang2, Jung-Fang Chen .JF,2011, An Entropy Decision Model for Selection of Enterprise Resource Planning System, International Journal of Computer Trends and Technology- March to April Issue 2011, ISSN:2231-2803, IJCTT,pp1-9

[16] Gong.J , Xu.J, 2006, The integration of valued outranking relations in ELECTRE methods for ranking problem, ISSN 1 746-7233, England, UK

[17] World Journal of Modelling and Simulation.Vol. 2 (2006) No. 1, pp 3 14, di akses $12 \quad$ September 2011 citeseerx.ist.psu.edu/viewdoc/download?doi=10.1.1.89.7500\&rep...

[18] Karacu.M, Arslan.T, 2010, Electre Approach for modeling Public Decision making behavior on Transportation Project Selection Process, 12th WCTR, July 11-15, 2010 - Lisbon, Portugal , intranet.imet.gr/Portals/0/UsefulDocuments/documents/03182.pdf

[19] Sevkli.M, 2010, An application of the fuzzy ELECTRE method for supplier selection, International Journal of Production Research, Vol. 48, No. 12, 15 June 2010, 3393-3405

[20] Cheng and regina, 2000, Development of a Fuzzy Multi criteria Decision support system for manucipal Solid Waste management, A thesis submitted to the faculty of graduate studies and research for degree of master of Applied Science in advance manufacturing and Production systems University of Regina, Kanada

[21] Zandi,F , Tavana.M and Martin.D, 2011,A fuzzy group Electre method for electronic supply chain management, International Journal of Logistics Research and Applications framework selection, International Journal of Logistics: Research and Applications Vol. 14, No. 1, February 2011, 35-60 Publication details, including instructions for authors and subscription information:

[22] J. Clerk Maxwell, A Treatise on Electricity and Magnetism, 3rd ed., vol. 2. Oxford: Clarendon, 1892, pp.68-73.

[23] I. S. Jacobs and C. P. Bean, "Fine particles, thin films and exchange anisotropy," in Magnetism, vol. III, G. T. Rado and H. Suhl, Eds. New York: Academic, 1963, pp. 271-350.

[24] K. Elissa, "Title of paper if known," unpublished.

[25] R. Nicole, "Title of paper with only first word capitalized," J. Name Stand. Abbrev., in press.

[26] Y. Yorozu, M. Hirano, K. Oka, and Y. Tagawa, "Electron spectroscopy studies on magneto-optical media and plastic substrate interface," IEEE Transl. J. Magn. Japan, vol. 2, pp. 740-741, August 1987 [Digests 9th Annual Conf. Magnetics Japan, p. 301, 1982].

[27] M. Young, The Technical Writer's Handbook. Mill Valley, CA: University Science, 1989.

[28] Gavish, B. and Gerdes, J.H., 1997, Voting Mechanisms and Their Implications in A Gdss Environment, Annals of Operations ResearchScience Publisher

[29] Deng H dan Wibowo, S, 2008, A Rule-Based Decision Support System for Evaluating and Selecting IS Projects ,Proceedings of the International MultiConference of Engineers and Computer Scientists 2008 Vol II IMECS 2008, 19-21 March, 2008, Hong Kong

\section{AUTHORS PROFILE}

Ermatita. Lecturer Sriwijaya University Palembang Indonesia.

Sri Hartati, Lecturer Gadjah Mada Univeersity Yogyakarta Indonesia.

Retantyo Wardoyo, lecturer Gadjah Mada University Yogyakarta Indonesia. Agus harjoko Lecturer Gadjah Mada University Yogyakarta Indonesia. 